\title{
Working towards sincere encounters in volunteer tourism: an ethnographic examination of key management issues at a Nordic eco-village
}

\section{Solène Prince}

To cite this article: Solène Prince (2017) Working towards sincere encounters in volunteer tourism: an ethnographic examination of key management issues at a Nordic eco-village, Journal of Sustainable Tourism, 25:11, 1617-1632, DOI: 10.1080/09669582.2017.1297450

To link to this article: https://doi.org/10.1080/09669582.2017.1297450

\section{Published online: 10 Mar 2017.}

Submit your article to this journal $\widetilde{ }$

Џll Article views: 617

Q View related articles $\asymp$

View Crossmark data \lceil

Citing articles: 8 View citing articles ¿ 


\section{Working towards sincere encounters in volunteer tourism: an ethnographic examination of key management issues at a Nordic eco-village}

\section{Solène Prince}

Department of Tourism Studies and Geography, Mid-Sweden University, European Tourism Research Institute (ETOUR), Östersund, Sweden

\begin{abstract}
This article explores host-guest dynamics at Sólheimar eco-village, Iceland to contribute to the conceptualization of transformative learning in volunteer tourism. At the eco-village, the host and volunteers come together to share similar goals and meaningful experiences. This interaction gets complicated, however: the eco-village exists within the global capitalist system and must operate using market norms. The idealist and educational expectations of the volunteers often clash with the practical short-term goals of the community: there are also cultural and experiential differences between the parties. This clash is used to discuss the importance of sincerity in volunteer tourism at the eco-village. Data were collected through fieldwork, primarily including participant observations and interviews, to help interpret the patterns of behaviors and perceptions of both parties in relation to the aim. Ultimately, the experience that binds host and guests cannot solely be about learning to do things alternatively and sustainably; it requires sincerity, using Taylor's 2001 sincerity concept, to tackle the difficulties in working alternatively and sustainably to attain this experience. It is argued that transformative learning during the volunteer experience in alternative spaces should be conceptualized to include the promotion of sincere encounters, and adjusted to concern both the host and its guests.
\end{abstract}

\section{ARTICLE HISTORY}

Received 30 November 2015

Accepted 14 February 2017

\section{KEYWORDS}

Volunteer tourism; eco-

village; Iceland;

transformative learning;

focused ethnography

\section{Introduction}

Many tourism scholars believe volunteer tourism can generate profound and genuine cultural exchanges between hosts and guests, making the practice an alternative to conventional tourism based on market interactions (McGehee, 2002; Zahra \& McGehee, 2013). Lately, theory aimed at conceptualizing the benefits of volunteer tourism has come to define its transformative potential for volunteers (Coghlan \& Gooch, 2011; McGehee, 2012; Mostafanezhad, 2014). Research in volunteer tourism has, moreover, expanded beyond disadvantaged communities. It has come to include volunteering on organic farms, where authors such as Kosnik (2014), McIntosh and Bonnemann (2006), Miller and Mair (2014, 2015), Mostafanezhad (2016), Terry (2014), and Yamamoto and Engelsted (2014) have broadened conceptions of volunteer tourism by assessing and praising the interconnectedness between the host and the guest in these alternative spaces. On organic farms, host and volunteer come together because they are both dedicated to a wider socio-environmental movement, such as more sustainable food production methods, ready to unite to work hard and learn from each other (Mostafanezhad, 2016; Terry, 2014). 
These conclusions from research on organic farm volunteering build stronger theories to conceive of volunteer tourism as an alternative activity with potential to generate transformative learning for guests involved in its practice. Some more critical scholars have nonetheless identified problems in volunteering in alternative spaces related to volunteer expectations and host realities (see, for instance, Deville, Wearing, \& McDonald, 2016; Mostafanezhad, 2016; Mostafanezhad, Suryanata, Azizi, $\&$ Milne, 2015). It remains that the volunteer's learning experience in alternative spaces, such as family farms, but also in eco-villages, is not usually researched in relation to the global structures and discourses that complicate sustainable and alternative living for the host. Learning is generally conceptualized in terms of bonds of intimacy, and mostly related to the life-changing experience of the volunteer. As Conran (2011) points out, a focus on intimacy leads to uncritical notions of the local dynamics, and consequently turns the volunteering experience foremost into a consumer good (see also Guttentag, 2009; Mostafanezhad, 2014; Palacios, 2010).

I turn to the concept of sincerity, presented by Taylor (2001), to address this shortcoming, by identifying ways that the host can fashion the version of the experience it deems appropriate to share as it interacts with volunteers. Sincerity implies that negotiations between host and guest are used to define the meaning of the culture encountered, instead of looking for objective cultural essences (Taylor, 2001). Sincerity would entail that volunteers are made aware of the fluid, confused and ongoing nature of the culture of their hosts (see also Amoamo, 2011; Hollinshead, 1998; Wearing \& Wearing, 2006). I argue that this can facilitate the critical reflection needed from the volunteer for their transformative learning experience to directly benefit their host. Accordingly, this study assesses the social dynamics of volunteer tourism at a host community founded by individuals striving for an idealist lifestyle. By exploring a Nordic eco-village, a type of space that has received little attention in tourism scholarship, this article contributes new insight about the pedagogical dimensions of volunteer tourism. The idealist nature of the eco-village makes it an interesting case to understand the potential and contradictions of volunteer tourism because it is a site in itself dedicated to the deconstruction of dominant discourses and the celebration of human interactions (see Global Eco-village Network; http://gen.ecovillage.org/). The members of eco-villages come purposely together to form a village, hamlet or neighborhood, where they live a lifestyle based on values they feel mainstream structures and discourses have eroded (Bang, 2007; Dawson, 2006; Jackson, 2004; Kirby, 2003; Van Schyndel Kasper, 2008).

This study takes an ethnographic approach as it aims to interpret the patterns of behaviors and perceptions of a particular social group, in this case, the eco-village and its volunteers. The data were collected primarily through participant observations and interviews, as well as through document analysis, over two periods of fieldwork at Sólheimar eco-village, considering the experiences with volunteer tourism of community members and volunteers alike. The findings ultimately demonstrate that the experience that binds the host and its guests cannot solely be about learning to do things alternatively and sustainably; sometimes, it is sincerity over the difficulty of doing things alternatively and sustainably that characterizes this experience. This argument is used to compel tourism researchers to re-conceptualize transformative learning during the volunteer experience in alternative spaces to include the promotion of sincere encounters, and moreover to consider it as something concerning also the host.

\section{Transformative learning in volunteer tourism}

Tourism scholars generally recognize volunteer tourism as an alternative form of tourism, which has seen significant growth globally in the last decades (Wearing \& McGehee, 2013). Volunteer tourism is widely considered as a holiday or time spent where the tourist is actively involved in serving the needs of a host community, such as through projects of cultural restoration, environmental conservation and/or economic and social development (Wearing, 2001). Many tourism scholars engaged with questions of social justice conceptualize volunteer tourism as an alternative form of tourism because it has the potential to offer smaller scale and closer contact with the host, generating a chance for 
informal, yet valuable, more profound cultural exchange than traditional tourism (Maclntosh \& Zahra, 2007; McGehee, 2002; McGehee \& Norman, 2001; McGehee \& Santos, 2005; Zahra \& McGehee, 2013). All these factors coalesce to link volunteer tourism to the concept of sustainable tourism. Volunteer tourism can be seen as a direct descendant from the alternative tourism ideas of the 1980s, advocating a "soft and humane tourism" that centers on localized goals going beyond economic profit (Krippendorf, 1987, p. 106).

There is concern in tourism scholarship over the unequal nature of the interactions that guests engage in at their volunteer tourism destination. More than with any other form of tourism, the guests penetrate local spaces on the premise that they will help communities overcome disadvantages that they do not have the agency or resources to overcome themselves. Simpson (2004) found that volunteer tourism in disadvantaged communities of the global south could maintain and even widen the gap between "us" and "them" when volunteer tourists make no commonality between what is developed and underdeveloped in their romanticized accounts of community and culture (see also Guttentag, 2009; Mostafanezhad, 2014; Palacios, 2010; Raymond \& Hall, 2008). For instance, Mostafanezhad (2014) found volunteers in Thailand who were disappointed that host community members would accumulate cellular phones and other modern technologies, that would, they felt, detach these local inhabitants from their authentic culture.

Conran (2011) outlines that a focus on intimacy overshadows the structural inequalities at the core of the volunteer tourism experience. Intimacy implies finding authenticity by experiencing what MacCannell (1976) called the back-stage, where the culture is deemed to be more authentic than what is usually staged for tourist consumption. Volunteers who describe their experience often perceive a sense of closeness and shared experiences with the host community, where they identify with the other through their active and prolonged involvement with the latter. Conran (2011) argues that intimacy is not usually critiqued from a cultural standpoint, and thus perpetrates uncritical notions of development among volunteers searching for cultural authenticity and interpersonal bonds. Development becomes, consequently, something of an experience to consume for the volunteer tourist, promoting a notion of development which disregards the complex discourses and structures that underpin global inequalities (Guttentag, 2009; Mostafanezhad, 2014; Palacios, 2010).

Tourism scholars have addressed the issue of uneven cultural encounters between host and volunteer by re-conceptualizing the benefits of volunteer tourism using pedagogical terms. Scholars no longer link volunteer tourism directly to international development, but rather perceive it as a chance to offer learning experiences aimed at deconstructing prevailing ideologies between cultural groups in affluent and less-affluent countries (Mostafanezhad, 2014). Authors such as McGehee (2002), McGehee and Norman (2001) and Mostafanezhad (2014) propose a shift from the promotion of lifechanging experiences for universal charity, to the support of social movement participation, where the engagement of the volunteers should engender their awareness of their implication in a greater cause than their personal enrichment. A notion that volunteers should be transformed into more critical and sensitive citizens of the world through their experience has thus become a major benchmark in the scholarly evaluation of volunteer tourism (Coghlan \& Gooch, 2011; Conran, 2011; Hammersley, 2014; McGehee, 2012, 2002; Simpson, 2004).

Self-development is thus commonly identified as an important aspect of volunteer tourism in scholarship (see also Bailey \& Russel, 2010; McGehee \& Santos, 2005; Maclntosh \& Zahra, 2007; Raymond \& Hall, 2008; Simpson, 2004). Under this light, transformative learning theory, stemming from adult education (Mezirow, 1991; O'Sullivan, 2002; Taylor, 2006), has even been applied to volunteer tourism to conceptualize the developmental benefits of the volunteer experience for the one engaging in the activity. Transformative learning, in large, denotes "experiencing a deep, structural shift in the basic premises of thought, feelings, and actions. It is a shift of consciousness that dramatically and irreversibly alters our way of being in the world" (O'Sullivan, 2002, p. 11). Rightly, transformative learning implies a disillusionment and the search for new frames of reference for the participant in volunteer tourism (Coghlan \& Gooch, 2011). 
The process of disillusionment and reflection anticipated in transformative learning is conceived in ten steps (Mezirow, 1991; Taylor, 2006), which have been described by tourism scholars as the responsibility of the sending organization and people in leadership positions to enable during the volunteer experience (Coghlan \& Gooch, 2011; Hammersley, 2014). Good volunteering programs are thus those that offer opportunity for reflection to their participants (Leigh, 2006). A structured educational approach is accordingly advocated in volunteer tourism for anything of personal or social value to derive from the activity (Simpson, 2004). Hammersley (2014) believes the sending organization should manage the experience of the volunteers before, during and after their stay, which would include facilitating conversations around the privileged nature of being a guest and the dynamics that constrain the host-community. Raymond and Hall (2008) propose the participants keep journals or write assignments to reflect over their experience. The volunteer experience is thus meant to foster ongoing critical reflection well before and beyond the participant's holiday to become a meaningful chance at deconstructing pervasive ideologies.

\section{The transformative experience in alternative spaces}

Research in volunteer tourism has expanded beyond disadvantaged communities in the global south. Recently, organic farm volunteering has received much attention from volunteer tourism researchers (see Kosnik, 2014; McIntosh \& Bonnemann, 2006; McIntosh \& Campbell, 2001; Miller \& Mair, 2014, 2015; Mostafanezhad, 2016; Terry, 2014; Yamamoto \&Engelsted, 2014). Under the banner of the Willing Workers on Organic Farms (WWOOF) movement, organic farmers and entrepreneurs around the world are hosting volunteers interested in working in exchange for accommodation and meals (see http://wwoofinternational.org/). Volunteers on organic farms are perceived to "mitigate local labor market failures" by filling in positions which farmers cannot afford through regular wages (Terry, 2014, p.95). This trend thus represents a greater social movement that serves to create a body of laborers working for a socio-environmental cause. To Maycock (2008) and Mostafanezhad et al. (2015), the popularity of these volunteer experiences stems from a growing awareness of our dependence on capitalist modes of production, which disconnect us from our food sources and from an authentic lifestyle.

Miller and Mair $(2014,2015)$ believe the volunteering holiday on an organic farm illuminates the transformative potential of volunteer tourism where tourists are open to learn new ways of living and doing things during their travels. Reciprocally, this involvement is considered to promote the social and environmental agenda of organic farmers who strive for better production and consumption patterns and who advocate improved lifestyle choices (Mostafanezhad et al., 2015; Mostafanezhad, 2016). Organic farms hosting volunteers become forums for actors to engage with each other over common interests in knowledge and skills development, and idealism and activism (Miller \& Mair, 2014, 2015). Kosnik (2014) highlights the reciprocity of the encounter between host and guest in the WWOOF context, claiming the experience offers a genuine form of hospitality that resembles the mutual support of a family, where all actors feel social obligations towards one another, such as sharing a meal or helping each other with domestic chores. Researchers thus generally see this type of holiday as more than a traditional work-exchange, and have broadened volunteer tourism theory by assessing the cultural interconnectedness built in these spaces between host and guest.

These conclusions build stronger theories to conceive of volunteer tourism as an alternative activity with the potential to teach new practices in organic farming and foster a lifestyle that defies the woes of global capitalism. They do not, however, conceptualize the pedagogical dimension of the organic farming holiday beyond intimacy. Alternative lifestyles are in other words not presented as ambitions affected by global structures and discourses. These experiences provide intimate contact with a host family, but they are nonetheless occurring on a challenging background that complicates the host's goals and practices. As explained next, the experiences of organic farmers are not solely defined by a culture of sharing, learning and promoting sustainability, though the WWOOF movement has its participants believe and expect that. 
Deville et al. (2016) caution that the WWOOF movement is showing signs of commodification more typical of conventional forms of tourism. The goals of these households are already multiple and contradictory as they strive for social change on a background of capitalist dynamics where they have to produce and sell goods and services to survive (Mostafanezhad, 2016). As they get involved in volunteer tourism, the contradictions they have to deal with are augmented, and it becomes increasingly difficult for them to perfectly live up to ideals of alternative living. Mostafanezhad (2016), in a case study on WWOOF farms in Hawaii, describes that despite their harsh critique against the agro-industrial complex, some farm hosts are forced to shop at large economy warehouses to afford feeding their volunteers because the food grown on their farms is too costly to give away. Weaver (2013) highlights that success triggers practices aimed at growth at destinations, despite an initial focus on alternative principles, as managers seek to increase revenues. Small groups and businesses can dismiss their initial ambition of staying small and alternative. Ultimately, when subjected to encounters with volunteers and guests, places like organic farms become more heterogeneous and standardized than their members initially intended (Deville et al., 2016). Coghlan and Noakes $(2012$, p. 28) hold that non-profit organizations are mostly left to tradeoff between "money and mission", and that these compromises will leave them with different degrees of commercialization and standardizations, rather than absolutes.

The economic goals of hosts are not always compatible with the personal goals of the volunteers. Mostafanezhad et al. (2015) contend that bulk buying, as well as long and unstructured working hours, expectations to do extra chores and a lack of family values at the host farm, could displease volunteers seeking experiences of personal development, who did not want to be solely considered as cheap labor by their host. The possibility to participate in various activities, the provision of comforts, and the chance for escape have been identified as conveniences commonly expected by participants in search of a personal experience in alternative spaces (Mclntosh \& Bonnemann, 2006; McIntosh \& Campbell, 2001; Yamamoto \& Engelsted, 2014). These expectations are to be catered for by a host who ultimately does seek economic benefits from cheap labor, leading possibly to tensions between the two parties due to their diverging expectations (Deville et al., 2016; Mostafanezhad, 2016).

\section{Rethinking learning in volunteer tourism}

Consequently, I argue that transformative learning in spaces such as organic farms and eco-villages cannot solely rest on notions of building better citizens through intimacy and the exchange of skills and ideas. Transformative learning may in fact be more adequate in its present theoretical form to discuss the potential and development of educational programs (see Bell, Gibson, Tarrant, Perry, \& Stoner, 2016; Tarrant, 2010; Tarrant \& Lyons, 2012). When it comes to volunteering in alternative communities, learning cannot be packaged as a commodity, as an educational program would be. The focus of tourism scholars on theorizing how volunteers can become better citizens is here problematic, in the sense that it pictures the host-community as a mere prop to be used as part of a learning experience. This dynamic does not fit well to host families and communities that come in direct contact with volunteers as they seek practical and ideological support on a background of challenging dynamics. Arguably, without a critical discussion between the hosts and guests about what it implies to practically handle the tensions intrinsic to alternative goals, the practice remains partly flawed for both parties.

The notion of sincere encounters in cultural tourism, presented by anthropologist John Taylor (2001), is here considered useful to re-imagine the learning process during the host-guest encounter. Taylor (2001) explains that sincerity represents a shift towards negotiation between host and guest over the meaning of their cultural encounter, instead of them looking for, or posing, as objective cultural essences. For Taylor (2001, p. 23): "The notion of sincerity is significantly different from that of authenticity in that it occurs in the zone of contact among participating groups or individuals, rather than appearing as an internal quality of a thing, self, or Other". It is ultimately a more critical approach 
to conceive of host-guest encounters, as the focus lies on the agency of the toured host, rather than on the volunteer's self-actualization. With this approach, both host and guest can participate in constructing new narratives for tourist spaces (Amoamo, 2011; Hollinshead, 1998; Wearing \& Wearing, 2006). Wearing and Wearing (2006) contend that this type of social interaction can be used to reinterpret and re-present destinations in unique ways, giving culture a fluid, confused and ongoing nature. Amoamo (2011), for example, discusses Maori operators who select, recollect and present their own stories of their colonial past, along with their modern-day context as post-colonial agents, by taking tourists on alternative tours. These tours teach that Maori culture is dynamic and in tune with the modern fabric of living in a global capitalist economy. Similarly, I propose that hosts can actively construct and share with guests their own version of sustainable practices and alternative living through their intimacy with their guests as the latter seeks to learn and contribute. This re-conceptualization is meant to present transformative learning as something potentially beneficial for both host and guest. This is explored further through the case study of Sólheimar eco-village in Iceland.

\section{Sólheimar eco-village}

With their strong ideals in the face of social struggles, eco-villages can teach tourism scholars interesting lessons about the practicalities of pursuing an alternative ideology while involving volunteers in the venture. Members of eco-communities come together to form a village, hamlet or neighborhood, where they live a lifestyle based on their shared idealized values (Bang, 2007). The body of shared values of these communities often relates to principles of social inclusion, spirituality, environmental sustainability, self-governance, practicality and/or religious ambitions (Dawson, 2006; Jackson, 2004; Kirby, 2003; Van Schyndel Kasper, 2008). The perception that the capitalist system erodes social bonds and ecological systems, disempowering producers and consumers alike, has provided some individuals with "impulse to move beyond protest and to create models of more sane, just and sustainable ways of living" (Dawson, 2006, p. 38).

The eco-village used in this study is Sólheimar eco-village, located close to the small town of Selfoss, about $60 \mathrm{~km}$ east of the Icelandic capital, Reykjavik (see http://www.solheimar.is/en/). It was founded in 1930 by Sesselja Sigmundsdóttir who wanted to help orphaned children with mental handicaps by creating a space for them to develop (Bang, 2002). Sesselja's project started as a summer-time operation, but eventually took root. The space grew into a permanent village of about 100 inhabitants, with a number of facilities to accommodate the aging children, becoming a place where adults with mental conditions (e.g. autism, Down syndrome) of varying levels found space for integration, well-being, valorization and development. Residents with a mental handicap now compose about $45 \%$ of the village's population. These individuals work at the different businesses and workshops that have flourished at Sólheimar over the years or at other positions around the villages. Their tasks correspond to their abilities and are meant to stimulate feelings of self-worth and inclusion. Individuals without mental-handicaps fulfill administrative and coordinative duties, and have to adapt to the form of organization the disabled residents necessitate to live and work in the village (Bang, 2002).

Sesselja, early on, developed organic gardening and other techniques for self-subsistence at her village (Bang, 2002). The promotion of organic materials, the restoration of the earth and locally based food production and processing are at the heart of the companies and workshops the village has developed over the years. Sólheimar now features buildings with low environmental impact and is self-sufficient in energy through geothermal sources. The six artisanal workshops of the village produce crafts made of a variety of organic and natural materials. The businesses of the village are: an organic greenhouse, a tree nursery and a center for sustainability and environmental education built in 2002. The Global Eco-village-Network (GEN) declared Sólheimar the first Icelandic eco-village in April 1997. Education is often a goal of eco-villages, especially for those that are part of the GEN movement (Jackson, 2004). Sólheimar now hosts a number of educational opportunities through different partnerships at its education center. 
Sólheimar is at a stage where its division of labor, social traditions and economic structure are well established. Its economic subsistence depends on subsidies from the Icelandic state, profit generated at its local businesses and financial support from affiliated businesses and private donors. The administration of the Sólheimar community invites interns on its own account and volunteers from different external programs to participate in various local social, environmental and economic activities for periods ranging from a few weeks to a year. Volunteers and interns live in the village in special accommodation and participate in all aspects of its daily life, which includes attending communal lunches, morning meetings and social events, and showing initiative to contribute to the community beyond assigned tasks. They work and play alongside the handicapped residents during the day and at events, and are encouraged to socialize with them as part of their experience.

\section{Methodological framework}

I used focused ethnography to study the social patterns formed by the host and guests at Sólheimar. This form of ethnography entails that the researcher's study is guided by specific research questions, rather than aimed at widely observing a cultural group (Knoblauch, 2005; Wall, 2015). As any ethnography, this method implies some form of immersion in the daily lives of people from a culture-sharing group where the researcher seeks to identify discernable behavioral, belief, value and linguistic patterns (Wolcott, 2008). However, this specific method is mostly used to research emerging cultural contexts where social patterns are found in common affinities, perspectives, goals and interests, rather than in a culture-sharing group foreign to the researcher in a cultural sense (Knoblauch, 2005; Wall, 2015). Specifically, I gathered data relating to the social patterns host and guests form as they interact at Sólheimar in order to study the dynamics of learning during the volunteer tourist experience at the eco-village.

I chose Sólheimar to research volunteer tourism because it has a well-established tradition of working with volunteers and because its goals of social integration and environmental education make it a special case to study transformative learning. My previous involvement at the village as an intern facilitated my access to the community through key informants and ensured I had grounded knowledge of the context and people I was about to study. During my internship, I integrated with the Sólheimar community for three months in the fall of 2010. I worked on educative projects, helped at the organic greenhouse, and participated in a variety of local activities. I joined the community again in February 2015 for six weeks, as a researcher to pursue participant observations and interviews to complement and re-orientate the conclusions I had drawn from my first visit in order to use Sólheimar as a proper case study.

To warrant the validity of my study, it was crucial that I sustained and maximized my contact with volunteers and community members throughout my fieldwork. Ethno-methodologies such as participant observation are often considered to depend on the ability of the research to uphold positive social relations with the study participants (Frohlick \& Harrison, 2008). As Hammersley (2014) writes, membership and the researcher status are more like complements, rather than contradictions during the data collection process of the researcher involved as an observer in the field. Hammersley's (2014) own research has been "based on a sense of mutual understanding and shared confidence between the researcher and research participant" (p. 861). The membership status I acquired during my fieldwork positioned me as a volunteer, probably since I was a foreign young adult and ready to help, like volunteers usually are at Sólheimar. This status helped me approach community members and volunteers alike, but it also complicated my data collection in some instances as I will explain. Also, it is possible that my affinity with the volunteers has skewed my result towards their perspectives, though I tried as much as possible to balance the situation with interviews and interactions with community members.

Many ethnographic researchers embrace the practice of listening in their ongoing engagement, highlighting the importance of conversation during the immersion process (Forsey, 2010; Hockey, 2002). I gathered much of my data through on-site overt informal conversational interviews during 
daily activities where I engaged volunteers and community members in their context of experience (i.e., their work place, social spaces such as the lunch hall and community events) when appropriate. It was important to allow topics to emerge naturally throughout my research. Kitchin and Tate (2000) write that on-site informal conversational interviews help lead to a greater recognition of the subject's points of view. The close contact with the social group also eased the validation process as continual member-checking could be done casually throughout fieldwork with different actors as I made sense of my interpretation (Creswell, 2013).

I participated in the same activities as the volunteers, including volunteering, for the sake of observation and conversation, and shared their accommodation for convenience. For that, it made it easy to approach people with overt questions and observe the 15 guests that made up the volunteers of the community throughout my fieldwork. I believe this close contact worked to position me as a volunteer in the eyes of the community members, and, significantly, in those of the coordinators of the educational center. I was sometimes asked by them to help out with activities that did not relate to my observations such as tour guiding and cleaning. I felt compelled to do these things in order to show my respect to my host. I did nonetheless eventually get access to eight reports written by previous volunteers where they reflected on their experience. I also reviewed my own final report from my time as an intern at Sólheimar. It was also relatively easy to informally approach the disabled residents during fieldwork as the volunteers share many of the same spaces as them.

I relied on formal interviews with five key individuals in the community with close involvement with volunteers. These interviews were done in English, which was not problematic as these participants were proficient in the language. I interviewed the two coordinators of the educational center as they coordinate the volunteers who come to the village by overseeing the selection process, welcoming them, and attending to their integration. It was paramount to interview the managers of the organic greenhouse and tree nursery as these individuals get the largest share of volunteers who come to the village working for their businesses. I also interviewed the manager of the wood workshop to secure more depth concerning the viewpoint of community members involved with creative workshops (though creative workshops accept very few volunteers). I did not record the interviews, as they often occurred in noisy common areas (like the coffee house or lunch hall) and work places (like the greenhouse and the educational center). Meeting the interview participants in their realm of involvement was done to prevent the development of uneven relations between researcher and respondents which is often associated with the interview setting, and it allowed me to observe these people in their context of involvement (Anderson, 2004; Anderson \& Jones, 2009). This situation, however, prevented the use and analysis of substantial quotes.

The other members of the Sólheimar community were approached through ongoing casual onsite conversations and contextual observations. I had wished to interview these people in a more formal way, but quickly realized that these participants questioned the need for a formal setting to discuss everyday topics with someone they considered a volunteer, preferring to chat on the spot. As Caton (2013) argued, methodological choices often stem from the researcher's sensitivity towards the research participants. I nonetheless always informed them of my role as a researcher during conversations. These individuals were: the music teacher, the social coordinator, the manager of the bakery, the disabled residents and their support staff, the manager of the store and boutique, different employees at the businesses and the other managers of creative workshops.

I centered my conversations and observation with volunteers on why they came to Sólheimar, their background, what they appreciated and disliked about their experience, their overall impressions and the lessons they were learning at the community. With the staff of the village, discussions and observations centered on how it was to host and work with volunteers, what kind of people they preferred, and also the challenges of hosting and working with volunteers. With the disabled residents, the observations rested on their interactions with volunteers; were these positives? Were they gaining something from each other? I noted all the information from my formal interviews, conversational on-site interviews and daily observations as field notes in a diary throughout my fieldwork. For the analysis, I generated a description of the themes that characterize the social interactions of the 
host and the volunteers at Sólheimar. The different data were triangulated to generate corroborating evidence to validate the relevance of these themes (Creswell, 2013). To further ensure the validity of my conclusions, I contacted two volunteers and the coordinators of the educational center for member-checking. While the volunteers responded with feedback, only one of the coordinators wrote me back, though mostly as a thank you for sharing my work than to give feedback on my conclusions.

\section{Findings}

Sólheimar eco-village is prepared to offer learning experiences in sustainable practices and foster social relationships with its volunteers and interns. Similarly to what Kosnik (2014) and Miller and Mair $(2014,2015)$ found on organic farms, the exchange of knowledge and building of bonds between the volunteers and the community members at Sólheimar was found to be significant to the dynamics of volunteer tourism. As Terry (2014) advanced on WWOOF as a social movement aimed at overcoming a shortage of labor in a low-profit sector, Sólheimar as an eco-village needs volunteers to help produce its labor-intensive organic and eco-friendly goods. The different managers are aware that, without the volunteers, their organic enterprises would not fare so well at Sólheimar. This gratitude develops in interpersonal relations where the work rests not only on the dedication to the greater cause, but also has its foundation in intimacy between host and guest where learning and sharing ideas is beneficial to both parties.

The interactions of the volunteers with the disabled community members are also conducive to self-development akin to transformative learning. The statement of this volunteer on her final report for her sending organization demonstrates the positive social outcome of these relations:

I learned how to work and live with disabled people at Sólheimar. Living there taught me to see the disabled people as equal members of our society and took away my fears of contact with them. It also taught me to be more patient and let them make their own experiences.

The disabled community members also expressed a lot of affection for the volunteers. They often sought hugs from them, especially at the morning meeting, and approached them for small talk and laughter during the day, which the volunteers appreciated. Under this light, the volunteer experience at the eco-village follows principles of alternative tourism as it offers intimate contact between host and guest, and aims at greater social change through cultural, interpersonal and skills exchange (MacIntosh \& Zahra, 2007; McGehee, 2002; Zahra \& McGehee, 2013).

The overall dynamics of the volunteers and interns' learning experience is, however, a more complex issue than a simple matter of intimacy with the host-community. As I discuss next, the complexity stems mainly from the difficulties the community itself faces as it attempts to reconcile its alternative goals in a context of capitalist norms, and from the lack of structure in the volunteer and intern programs to address the practical and critical meaning of these difficulties. This information is used to highlight how sincerity has the potential to benefit the volunteers and the alternative community in their transformative journeys.

\section{Staging sustainability}

As Mostafanezhad (2016) explains, alternative spaces also have concerns over their economic sustainability as they strive to function within the capitalist system. Sólheimar is no different. Inviting volunteers to contribute cheap labor, seeking to form new partnerships to get more working and paying guests, through which projects are made up to attract them and spaces are aesthetized to please them, and imposing mainstream notions of project development to volunteers, are examples of the complexity of following alternative goals and offering learning opportunities through market logics simultaneously at Sólheimar. The educational center, for instance, involves its volunteers in projects related to sustainability and environmental education, such as preparing exhibitions, marketing the facilities to school groups, researching information on sustainable practices and writing up reports. It 
became difficult to establish if all these projects are beneficial to the community and sustainable principles in general or simply done to suit the increasing number of volunteers, interns and student groups visiting Sólheimar in search of hands-on experiences.

This anecdote about a student group underlines this ambiguity. One afternoon, Valdemar, ${ }^{1}$ a man on the municipal board, visited the coordinators of the educational center. ${ }^{2}$ He was there to discuss with them their plan to involve American university students from an established semester program at Sólheimar in the sustainable planning of the municipality. Eventually, Valdemar admitted he had little hope for the initiative. The students would most likely just look up information on the Internet and the municipal board would browse through their reports for anything of interest. To Valdemar, the initiative was more to give the students a learning experience so that their program would be worthwhile. While pleasing paying guests is beneficial to the economic subsistence of the educational center, it might not fulfill the goals of the municipality who seeks to use Sólheimar's know-how effectively.

The educational center seeks to attract groups to use its facilities and educational expertise. Its coordinators are developing online promotional material and are actively looking for partnerships and other types of deals. Volunteers are also involved in helping with this promotion. The developments are mostly for economic purposes, which raises the issue Deville et al. (2016) and Mostafanezhad (2016) highlight about reconciling idealist goals of alternative practice with catering for the needs of the guests. The education the center promotes, the accommodation and food it provides and the setting it offers to these groups all need to appeal to customers, not free-floating idealists with little money. While an intern, the coordinators of the center asked me to propose ideas to improve the sustainability of the two guesthouses. I suggested a wall with pictures and quotes to illustrate the social vibrancy of the Sólheimar community. The coordinators dismissed the idea because the guesthouses had to keep a certain aesthetic to appeal to mainstream customers. The projects given to volunteers at the educational center reflect the aims of the coordinators as managers of a profit-seeking business, rather than of a space for the development of creative ideas. The attitude of the coordinators reflects the compromises idealist managers have to make between mission and money (Coghlan \& Noakes, 2012). Sustainability is then staged, to use MacCannell's (1976) term, in ways to attract guests, students and volunteers. The projects given to students, interns and volunteers, and the decor in which it takes place are more about invoking appealing images of sustainability than communicating the difficulties of driving forward complex projects.

These types of incremental short-term activities at Sólheimar at times displease and confuse volunteers seeking to contribute to the community's longer term vision. It was found that the volunteers often dismissed the economic pillar in their notion of sustainability. Some volunteers described the village as too "commercial" due to the market-driven dynamics of Sólheimar. They deplored that a lot of emphasis goes on producing goods and services at the different businesses and workshops, disregarding that the community members wish to promote the economic subsistence of the village. The focus on productivity implied for some volunteers that those running Sólheimar see them as workers, rather than apprentices or sources of creativity. Mostafanezhad et al. (2015) found similar results in Hawaii where volunteers were leaving host farms where they felt they were only used for labor. The authors then conclude that eventually: "the farmer's goal of affordable and reliable labor begins to contradict with the volunteer's goal of meaningful experience" (Mostafanezhad et al., 2015, p. 132). When sustainability and alternative living are staged to offer an experience to the volunteer, it is inevitable that the tensions related to the complexity of fulfilling contradictory goals will complicate the host-guest relationship.

\section{Reflecting on self and participation}

Sólheimar's coordination of its volunteers mostly lacked the educational structure related to and for the transformative learning which Hammersley (2014), Coghlan and Gooch (2011), Simpson (2004), and Raymond and Hall (2008) proposed, where sending organizations arrange briefing, and diaries 
record moments of reflection and critical discussions before, during and after the volunteer holiday. All the volunteers who come to Sólheimar got an information session from the coordinators of the educational center or other volunteers to learn about the local history and organization. There were also sometimes meetings with the coordinators during the stay of the volunteers. When I was an intern, our group of six sat down during its last week of volunteering and we discussed the lessons that we learned from our experience in the community. This type of concluding session became more of a farewell get-together, as I came back to do research. With the growing number of volunteers, their sojourns not all synchronized and the work load of the coordinators increased, the volunteers became more difficult for the coordinators to supervise, I was informed. Their conversations with them were observed to be more about how to improve their management (mostly solving interpersonal conflicts among volunteers and persuading them to clean their accommodation) than to reflect critically on their experience.

There are volunteers writing final reports, but these are done to fulfill the requirements of a sending organization or university program. The volunteers who come through the European Volunteer Service (EVS) (a European program that finances the year-long participation of volunteers in accredited projects within the continent), for instance, meet with the organization in Iceland before and during their experience and write a report at the end of their stay specifying their learning outcomes, such as communicating in a foreign language and developing civic and social competences. These EVS reports show little purpose for debating the meaning of alternatives and sustainability at the eco-village, focusing mostly on the personal and social development of the volunteer. One volunteer wrote in her report:

I had the opportunity to share my daily life with people with disabilities. It gave me the opportunity to get to know different [kinds of] pathologies and different [kinds of] people. I lived with 14 other workers and volunteers from Iceland and around Europe. It has been a great opportunity to get to know other cultures and become more tolerant and compassionate.

Simpson (2005) writes that gap years abroad serve to prepare a better pool of civil servants. The underlying goals of the EVS align with the professionalization of idealist work, as they are about panEuropean cooperation and the development of competent social individuals. The goals of Sólheimar are not directly included in the reflection process the EVS encourages its participants to do. This situation resembles the typical negative issue with volunteer tourism where the experience, in this case the learning experience, of the volunteer becomes more important than local goals (Guttentag, 2009; Palacios, 2010). The encouragement of such a reflection process, mostly linked to global citizenship, challenges the idea that a third party can effectively enable a process of critical thinking for the hostcommunity's sake that goes beyond the volunteer's personal development.

Sin (2010) explains that volunteers tend to frame their experience according to their own needs, and thus end up reinforcing uneven dynamics where the guest assumes an authoritative position over the host. Gunnar expressed discontent with some volunteers and their overwhelming focus on projects they designed themselves for their own interest or their requests to change workplaces for fun, instead of focusing on local needs. During my internship, for instance, two interns did not want to help carpenters build the new roof of the volunteer accommodation because they preferred to work on projects they had designed themselves. This further highlights how volunteer tourism often pushes the Sólheimar administration to negotiate its goals against, rather than aligning with, the experience of self-actualization of volunteers and guests.

Vigdis, the other coordinator of the educational center, claimed that some volunteers disregard how sustainability works in practice. She believes it is important for the community that the volunteers do "the small things", like picking vegetables and packaging goods. She maintains that the community moves forward by becoming self-sufficient economically and by diffusing its eco-friendly products. Similarly, in my own report, written following my internship at Sólheimar to get credit points from my home institution, one of my reflections was that sustainability required as much physical work as creativity and intelligence. Reconciling idealist goals in the physical world and within the 
capitalist system is part of the reality of the eco-village, and volunteers should learn this, to not only critically think of their personal experience, but also about their role within a community negotiating its position in a wider system.

\section{Searching for sustainability}

The volunteers at Sólheimar are conscious of the importance of social reform and sustainable practices. Many of them are vegetarians, educated in environmental and social studies and/or involved in activism at home (see also Conran, 2011; McGehee \& Santos, 2005; Wearing, 2001). As they integrate in the Sólheimar community though, the volunteers are faced with the application of ideas incompatible with their ideals and standards of sustainability. The volunteers were often found to criticize the sustainability of Sólheimar in its physical and managerial design, but also in the behavior of its members. This criticism related generally to the food wasted at the lunch hall and store, the use of cars within the village by the community members, the inefficient treatment of wastewater and, more generally, to the Icelanders' overconsumption of resources.

Besides these concrete transgressions, the fuzziness of the concepts of sustainability and eco-living also fostered futile criticism. For instance, Àrni, who works as the social coordinator of Sólheimar, was very enthusiastic about a troll garden project. The troll garden is the name of an area in the village built for socializing. Àrni designed the garden so the handicapped community members could grow herbs and flowers, and there is a small stage for anyone wishing to perform for an audience. However, I read a comment from a volunteer on the sustainability of the village stating there were too many aestheticized spaces at Sólheimar, instead of letting nature grow freely. From the perspective of this volunteer, a project like the troll garden is not a contribution to alternative principles, unlike what Àrni thinks.

To some residents, the discontent of the volunteers over the sustainability of their village is connected to the volunteers overlooking the complexity of sustainability by focusing too strongly on its environmental aspect. Gunnar explained the volunteers critical of their environmental practices failed to understand that, as an old community built initially for charity, the ecological aspects of sustainability at Sólheimar are still in a stage of progress. Sólheimar is working hard to make this transition, he explained. I found that many community members have a different notion of environmental sustainability than the volunteers, because of their Icelandic context. As their country runs fully on renewable energy and has plenty of water, Icelanders generally see energy and water as infinite resources. This is contrary to the behavior and principles that many volunteers developed as conscious consumers in their homelands, and would not be a good practice to bring back to countries with limited resources. Again, discontent from both parties can be linked to a lack of communication directed at framing the volunteers' role and experience at the community.

There was nonetheless communication between host and guests during daily interactions that went beyond simple intimacy and unproductive criticism. One form of learning for the volunteers occurred through their conversations among themselves and through their interactions with members of the community with whom they had built the close bonds described earlier. For Taylor (2006) and Hammersley (2014), transformative learning occurs through the development of bonds of support, trust, friendship and intimacy, where the learner develops critical skills through the assistance of a sensitive facilitator and the support of others. The members of the Sólheimar community with whom the volunteers interact daily were observed to be significant parts of this experience. For instance, evening discussions at the volunteer accommodation often related to the criticism the volunteers heard from workshop leaders and other community members about the management of the village, which led them to question aspects of eco-village governance. I also saw that many members of the Sólheimar community are comfortable discussing with volunteers their discomfort over the commercialization of the art of the handicapped residents. On one particular occasion, Solveig, a workshop manager, debated extensively with a few volunteers the ethics of reproducing and selling the designs of the handicapped residents for profit. These kinds of exchange are akin to the sincerity, 
with its notion of re-interpretation and fluidity, advocated by Taylor (2001), Amoamo (2011), and Wearing and Wearing (2006), which gives more cultural agency to local actors.

These types of discussions lead volunteers to see the back-stage of eco-living under a more critical lens, reacting to these types of interactions with statements I noted down such as: "It made me think about the ethics of delivering care in isolated communities" and "Sustainability? What is sustainability? I don't know anymore!" These reactions are more in line with the ambiguity the coordinators of the educational center and the different managers have to deal with daily. They also highlight how sincerity between the two parties, where the host is involved in the construction of the meaning of the experience at stake (Taylor, 2001), can be related to the unsettling aspect of the learning experience for the volunteers. The moment of interaction, where the community members are free and at ease to provide with their own narratives of sustainability and alternative living, becomes a valuable educational site. Intimacy can thus pave the way for the development of sincere encounters, giving the volunteers and community members alike a forum to redefine more fairly notions of sustainability, cultural norms and alternative lifestyles.

\section{Discussion and conclusion}

Sólheimar is one eco-village hosting volunteers among many others around the world, which are at different stages in their development and involvement with volunteers. This case nonetheless sheds light on the dynamics of volunteer tourism when a community comes together to live and work with idealist goals in mind. The experience of this eco-village with volunteers shows similarities to the experience of organic farms with volunteers described by Kosnik (2014), Miller and Mair (2014, 2015), Terry (2014), and many others, who have praised the interconnectedness fostered in these spaces. At Sólheimar, social integration and eco-living are key factors bringing together host and volunteers. The findings, however, reveal that the eco-village follows mainstream norms of growth and development. At Sólheimar, both volunteers and community members pursue the realization of certain projects and practices, which contests their attention to and criticism towards mainstream norms. The ensuing tensions between the idealist volunteers in search of personal development and the practice-oriented community members were used to open a discussion on the dynamics of transformative learning in tourism. This discussion highlighted the complexities for communities of handling the practicalities of their short-term goals in a market economy, while involving volunteers in a vision for long-term social and environmental action.

Through the ethnographic approach, it was possible to examine the everyday implementation of the multiple endeavors and strategies enacted at Sólheimar. These findings support the point made by Mostafanezhad (2016) and Mostafanezhad et al. (2015) that alternative spaces strive within mainstream capitalism and adhere to its norms in some ways, even if they aim to resist them. When key actors do not present sustainability and alternative living as contested matters at the eco-village, as Coghlan and Gooch (2011), Hammersley (2014) and Mostafanezhad (2014) suggest doing with international development in the global south, there is less chance for a holistic transformative learning experience to occur. What is important is that the host and the guest understand how the other party conceptualizes matters such as alternatives and sustainability, and debate constructively how shortterm goals can/should be reconciled with a long-term vision in the face of the status quo. The difficulty of negotiating economic sustainability with environmental and social sustainability at Sólheimar is a prime example of why this type of volunteer tourist experience needs to be promoted beyond matters of intimacy and self-development, and adopt sincerity, as described by Taylor (2001), as a strategy. That Sólheimar aims to mass-produce its goods and aesthetize its services, should be sincerely discussed by coordinators, community members and guests to assess the reality of running an eco-village in the twenty-first century. When the volunteers do not grasp the meaning of the structures and discourses behind what is expected of them, unpleasant frictions and lack of meaningful participation can ensue, and at the expense of the community. 
The bonds developed between host and volunteer matter in the promotion of sincere discussions over local issues such as behavioral impacts, eco-village governance and the purpose of physical labor. The transformative experience that binds the host and its guests together cannot solely be presented, by researchers and intermediaries alike, to be about learning to do things alternatively and sustainably through an educational approach focused, on the one hand, on the self-development of volunteers and, on the other hand, their hard labor. More honesty is needed on the behalf of sending organizations, people in leadership positions, and movements such as WWOOF over the difficulties faced by alternative hosts in the present context. It is argued that when sincere encounters are not central to the conceptualization of transformative learning in volunteer tourism, the host-community becomes a mere pawn to enrich volunteers, not a meaningful agent nor a benefactor in the practice. Without this consideration, volunteer tourism ultimately mostly remains an experience to consume for the volunteers (Guttentag, 2009; Palacios, 2010; Sin, 2010). That communities establish strong goals for themselves by adopting a vision of a better world and become empowered to communicate, but also revise, their goals and visions through their direct interactions with volunteers in ways they deem appropriate is suggested as a benchmark to make volunteer tourism more fair and emancipatory for all parties involved. It is not only the sending organization that can develop critical volunteers, which scholars have generally noted in their definition of transformative learning; the community members have a responsibility and interest in this experience too. Further research in volunteer tourism could give more attention to the transformative experience of the alternative community and suggest more specifically the practical changes needed for it to flourish.

\section{Notes}

1. All names are pseudonyms.

2. Sólheimar is located within the Grímsnes- og Grafningshreppur municipality. In Iceland, an elected council governs and administers the provision of a number of services such as waste management and schooling in municipalities. Sólheimar nonetheless mostly administers itself independently of the latter, due to its special status.

\section{Acknowledgments}

I would like to acknowledge my two supervisors at Mid-Sweden University, Dimitri loannides and Sandra Wall-Reinius, for their comments on this article.

\section{Disclosure statement}

No potential conflict of interest was reported by the author.

\section{Notes on contributor}

Solene Prince is a PhD student at Mid-Sweden University researching the complexities and tensions found in alternative tourism within rural and idealist spaces. Her research has taken her to Iceland and Denmark and touches upon subjects related to volunteer tourism, rural tourism and non-representational landscape theory.

\section{References}

Amoamo, M. (2011). Tourism and hybridity: Re-visiting Bhabha's third space. Annals of Tourism Research, 38(4), 12541273.

Anderson, J. (2004). Talking whilst walking: A geographical archaeology of knowledge. Area, 36(3), 254-261.

Anderson, J., \& Jones, K. (2009). The difference that place makes to methodology: Uncovering the 'lived space' of young people's spatial practices. Children's Geographies, 7(3), 291-303.

Bailey, A., \& Russel, K. (2010). Predictors of interpersonal growth in volunteer tourism: A latent curve approach. Leisure Sciences, 32, 352-368. 
Bang, J.M. (2002). The Camphill Network: Reversed integration of the differently abled. In J. Hildur \& L. Svensson (Eds.), Eco-village living: Restoring the Earth and Her people (p. 82). Totnes: Greenbooks.

Bang, J.M. (2007). Growing eco-communities: Practical ways to create sustainability. Edinburgh: Floris Books.

Bell, H.L., Gibson, H.J., Tarrant, M.A., Perry, L.G., \& Stoner, L. (2016). Transformational learning through study abroad: US students' reflections on learning about sustainability in the South Pacific. Leisure Studies, 35(4), 389-405.

Caton, K. (2013). Between you and me: Making messes with constructivism and critical theory. Tourism Culture \& Communication, 13(2), 127-137.

Coghlan, A., \& Gooch, M. (2011). Applying a transformative learning framework to volunteer tourism. Journal of Sustainable Tourism, 19(6), 713-728.

Coghlan, A., \& Noakes, S. (2012). Towards an understanding of the drivers of commercialization in the volunteer tourism sector. Tourism Recreation Research, 37(2), 123-131.

Conran, M. (2011). They really love me! Intimacy in volunteer tourism. Annals of Tourism Research, 38(4), 1454-1473.

Creswell, J.W. (2013). Qualitative inquiry and research design: Choosing among five approaches (3rd ed.). London: Sage.

Dawson, J. (2006). Ecovillages: New frontiers for sustainability. White River Junction, VT: Chelsea Green.

Deville, A., Wearing, S., \& McDonald, M. (2016). Tourism and willing workers on organic farms: A collision of two spaces in sustainable agriculture. Journal of Cleaner Production, 111, 421-429.

Forsey, M.G. (2010). Ethnography as participant listening. Ethnography, 11(4), 558-572.

Frohlick, S., \& Harrison, J. (2008). Engaging ethnography in tourist research: An introduction. Tourist Studies, 8(1), 5-18.

Guttentag, D.A. (2009). The possible negative impacts of volunteer tourism. International Journal of Tourism Research, 11 , 537-551.

Hammersley, L.A. (2014). Volunteer tourism: Building effective relationships of understanding. Journal of Sustainable Tourism, 22(6), 855-873.

Hockey, J. (2002). Interviews as ethnography? Disembodied social interaction in Britain. In N. Rapport (Ed.), British subjects: An anthropology of Britain (pp. 209-222). Oxford: Berg.

Hollinshead, K. (1998). Tourism and the restless peoples: A dialectical inspection of Bhabha's halfway populations. Tourism, Culture and Communication, 1(1), 49-77.

Jackson, R. (2004). The ecovillage movement. Permaculture Magazine, 40, 25-30.

Kosnik, E. (2014). Work for food and accommodation: Negotiating socio-economic relationships in non-commercial workexchange encounters. Hospitality \& Society, 4(3), 275-291.

Kirby, A. (2003). Redefining social and environmental relations at the ecovillage at Ithaca: A case study. Journal of Environmental Psychology, 23, 323-332.

Kitchin, R., \& Tate, N.J. (2000). Conducting research into human geography. Edinburgh: Pearson Education.

Knoblauch, H. (2005). Focused ethnography. Forum Qualitative Sozialforschung/Forum: Qualitative Social Research, 6(3), Art. 44.

Krippendorf, J. (1987). The holiday makers: Understanding the impact of leisure and travel. London: Heinemann.

Leigh, D. (2006). Third cultured volunteer tourists and the process of re-assimilation into home environments. Australian Journal on Volunteering, 11(2), 59-67.

MacCannell, D. (1976). The tourist: A new theory of the leisure class. Berkeley: University of California Press.

McIntosh, A., \& Campbell, T. (2001). Willing Workers on Organic Farms (WWOOF): A neglected aspect of farm tourism in New Zealand. Journal of Sustainable Tourism, 9(2), 111-127.

Macintosh, A., \& Zahra, A. (2007). A cultural encounter through volunteer tourism: Towards the ideals of sustainable tourism? Journal of Sustainable Tourism, 15(5), 541-556.

McIntosh, A.J., \& Bonnemann, S.M. (2006). Willing workers on organic farms (WWOOF): The alternative farm stay experience? Journal of Sustainable Tourism, 14(1), 82-99.

McGehee, N.G. (2002). Alternative tourism and social movements. Annals of Tourism Research, 29(1), 124-143.

McGehee, N.G. (2012). Oppression, emancipation, and volunteer tourism: Research propositions. Annals of Tourism Research, 39(1), 84-107.

McGehee, N.G., \& Norman, W.C. (2001). Alternative tourism as impetus for consciousness-raising. Tourism Analysis, 6(3-4), 239-251.

McGehee, N.G., \& Santos, C.A. (2005). Social change, discourse and volunteer tourism. Annals of Tourism Research, 32(3), 760-779.

Maycock, A. (2008). World Wide Opportunities on Organic Farms (WWOOF). Journal of Agricultural \& Food Information, 9 (4), 282-288.

Mezirow, J. (1991). Transformative dimensions of adult learning. San Francisco, CA: Jossey-Bass.

Miller, M.C., \& Mair, H. (2014). Organic farm volunteering as a decommodified tourist experience. Tourist Studies, 15(2), 191-204.

Miller, M.C., \& Mair, H. (2015). Volunteer experiences on organic farms: A phenomenological exploration. Tourism Analysis, 20(1), 69-80.

Mostafanezhad, M. (2014). Volunteer tourism: Popular humanitarianism in neoliberal times. Burlington, VT: Ashgate. 
Mostafanezhad, M. (2016). Organic farm volunteer tourism as social movement participation: A Polanyian political economy analysis of World Wide Opportunities on Organic Farms (WWOOF) in Hawai'i. Journal of Sustainable Tourism, 24 (1), 114-131.

Mostafanezhad, M., Suryanata, K., Azizi, S., \& Milne, N. (2015). "Will weed for food": The political economy of organic farm volunteering in Hawai'i. Geoforum, 65, 125-133.

O'Sullivan, E. (2002). The project and vision of transformative education: Integral transformative learning. In E. O'Sullivan, A. Morrell, \& M.A. O'Connor (Eds.), Expanding the boundaries of transformative learning: Essays on theory and praxis (pp. 1-12). New York, NY: Palgrave.

Palacios, C. (2010). Volunteer tourism, development and education in a postcolonial world: Conceiving global connections beyond aid. Journal of Sustainable Tourism, 18(7), 861-878.

Raymond, E., \& Hall, M.C. (2008). 'Make a difference!' The role of sending organizations in volunteer tourism. In K. Lyon \& S. Wearing (Eds.), Journeys of discovery in volunteer tourism (pp. 46-60). Cambridge, MA: CABI.

Simpson, K. (2004). 'Doing development': The gap year, volunteer-tourists and a popular practice of development. Journal of International Development, 16(5), 681-692.

Simpson, K. (2005). Dropping out or signing up? The professionalisation of youth travel. Antipode, 37(3), 447-469.

Sin, H.L. (2010). Who are we responsible to? Locals' tales of volunteer tourism. Geoforum, 41(6), 983-992.

Tarrant, M.A. (2010). A conceptual framework for exploring the role of studies abroad in nurturing global citizenship. Journal of Studies in International Education, 14, 433-451.

Tarrant, M.A., \& Lyons, K. (2012). The effect of short-term educational travel programs on environmental citizenship. Environmental Education Research, 18, 403-416.

Taylor, E.W. (2006). The challenge of teaching for change. New Directions in Adult and Continuing Education, $109,91-95$.

Taylor, J.P. (2001). Authenticity and sincerity in tourism. Annals of Tourism Research, 28(1), 7-26.

Terry, W. (2014). Solving labor problems and building capacity in sustainable agriculture through volunteer tourism. Annals of Tourism Research, 49, 94-107.

Van Schyndel Kasper, D. (2008). Redefining community in the ecovillage. Research in Human Ecology, 15(1), $12-24$.

Wall, S. (2015). Focused ethnography: A methodological adaptation for social research in emerging contexts. Forum Qualitative Sozialforschung/Forum: Qualitative Social Research, 16(1), Art. 1.

Wearing, S. (2001). Volunteer tourism: Experiences that make a difference. Cambridge, MA: CABI.

Wearing, S., \& McGehee, N.G. (2013). Volunteer tourism: A review. Tourism Management, 38, 120-130.

Wearing, S., \& Wearing, M. (2006). "Rereading the subjugating tourist" in neoliberalism: Postcolonial otherness and the tourist experience. Tourism Analysis, 11(2), 145-162.

Weaver, D. (2013). Asymmetrical dialectics of sustainable tourism: Toward enlightened mass tourism. Journal of Travel Research, 53(2), 131-140.

Wolcott, H.F. (2008). Ethnography: A way of seeing (2nd ed.). Walnut Creek, CA: Altamira Press.

Yamamoto, D., \& Engelsted, A.K. (2014). World Wide Opportunities on Organic Farms (WWOOF) in the United States: Locations and motivations of volunteer tourism host farms. Journal of Sustainable Tourism, 22(6), 964-982.

Zahra, A., \& McGehee, N.G. (2013). Volunteer tourism: A host-community capital perspective. Annals of Tourism Research, $42,22-45$. 